\title{
Characterization of entrepreneurial intention in university students as from Systemic Entrepreneurship Intention Model: a case study
}

\section{Caracterización de la intención emprendedora en estudiantes universitarios a partir del Modelo de Intención Emprendedora Sistémico: caso de estudio}

\author{
Jairo Adolfo Torres Velásquez ${ }^{1}$ \\ Alejandro Valencia Arias ${ }^{2}$ \\ JonAthan Bermúdez HeRnándeZ ${ }^{2}$ \\ Luisa Fernanda DíEZ-Echavarría ${ }^{3}$ \\ María Lucelly UrRego Marín ${ }^{1}$ \\ Fausto Orlando Maussa Pérez ${ }^{4}$
}

Corporación Universitaria Minuto de Dios-UNIMINUTO (Colombia)

Instituto Tecnológico Metropolitano (Colombia)

Universidad de Medellín (Colombia)

Recibido el 18 de julio de 2016, aceptado el 23 de marzo de 2017

Publicado online el 31 de octubre de 2017

$\mathrm{N}^{\mathrm{o}}$ de clasificación JEL: L26

DOI: $10.5295 / \mathrm{cdg} .160670 \mathrm{jt}$

\begin{abstract}
:
This paper presents a characterization of the entrepreneurial intention of university students in the city of Medellin. It is based on a quantitative methodological design from a self-administered questionnaire that was applied and validated to 879 students. This questionnaire collected data about the main factors reported in the Systemic Entrepreneurship Intention Model. Factors or components that describe behavior patterns when undertaking a new company were identified through a principal component and cluster analysis. The results
\end{abstract}

1 Faculty of Economic and Administrative Sciences. Corporación Universitaria Minuto de Dios - UNIMINUTO
Campus Bello, Cra. 45 No. 22D-25, Km 0 Freeway Medellín-Bogotá (Colombia). jairo.torres@uniminuto.edu;
murregomari@uniminuto.edu.co
2 Departament of Administrative Sciences. Faculty of Economic and Administrative Sciences. CLL 54 A 30-01
Neighborhood Boston - Campus Fraternidad of ITM. Parque i Medellín, (Colombia). jhoanyvalencia@itm.edu.co;
jonathanbermudez@itm.edu.co
3 Departament of Finances.Faculty of Economic and Administrative Sciences. CLL 54 A 30-01 Neighborhood
Boston - Campus Fraternidad of ITM. Parque i Medellín, (Colombia). luisadiez@itm.edu.co
4 Faculty of Economic and Administrative Sciences.Carrera 87 \#30-65, Medelliín(Colombia).fmaussa@udem.edu.co 
identify two factors that explain most of the data variance: the first one is the perceived viability by students to carry out processes of new companies, and the second one is the convenience factor that brings the creation a company. Furthermore, three groups or clusters of students with common characteristics in their entrepreneurial intention were identified. First, the "entrepreneurs" are characterized by having a positive attitude and aptitude regarding entrepreneurship. The second group is "neutral" and they are subjects partially affected or indifferent about wanting to start a new company. Finally, the group of "non-entrepreneurs" is composed of individuals who showed behavior of apathy towards entrepreneurship.

\section{Keywords:}

Cluster, entrepreneurial intention model, entrepreneurship, students.

\section{Resumen:}

Este artículo muestra una caracterización de la intención emprendedora de estudiantes universitarios de la ciudad de Medellín. Este estudio parte de un diseño metodológico cuantitativo a partir de un cuestionario autoadministrado aplicado y validado a 879 estudiantes, en el cual se recolectó información sobre los principales factores reportados en el Modelo de Intención Emprendedora Sistémico. Mediante un análisis de componentes principales y de clúster se lograron identificar los factores o componentes que describen los patrones de comportamiento en cuanto a emprender una empresa. Los resultados obtenidos identifican dos factores que explican la mayor parte de la varianza de los datos, el primero es la viabilidad percibida por los estudiantes para llevar a cabo procesos de emprendimiento y el segundo factor es la conveniencia que le reporta el crear una empresa. De otro lado, se lograron identificar tres grupos o clúster de estudiantes con características comunes y disímiles en su intención de emprender, el primero, los "emprendedores", que se caracterizan por poseer una actitud y aptitud positiva frente al tema; el segundo grupo el "neutro" el cual está parcialmente afectado o indiferente en cuanto a querer emprender una nueva empresa y el último los "no emprendedores", los cuales presentaron un comportamiento de apatía frente al tema.

\section{Palabras clave:}

Clúster, emprendimiento, intención emprendedora, modelo de intención emprendedora. 


\section{INTRODUCTION}

The intention of starting a company is viewed as the best predictor of its creation; however, it is uncertain how this evolves in time and why a long period may elapse between the time the intention was formed and the time when the potential entrepreneur starts the activities leading to its creation (Audet 2001).

Recognizing the importance and impact of entrepreneurship on economic growth and the implementation of public policies can serve as a tool for generating entrepreneurs and new businesses. This is why education in this matter must be regarded as a political strategy, so that it allows more individuals to make the decision to start up an enterprise (Liñán et al. 2010).

In this regard, Higher Education Institutions (HEI) as social transformers should provide an environment conducive to their students getting involved in processes of creation of new companies. Therefore, it is necessary to explore the factors that determine the intention of university students in creating a company. In this sense, the objective of this article is related to the generation of a characterization of entrepreneurial intent among university students, taking three HEI in the city of Medellín (Colombia) as a case study. To fulfill this, data from 879 self-administered questionnaires was analyzed, using as method an analysis of main components, which sought to determine factors affecting university students to have the intention to start up a company. To this end, the Systemic Entrepreneurial Intent Model was used, and using clusters, patterns of behavior were sought that could help explain the relationships between entrepreneurial variables.

This article initially addresses the conceptual framework on entrepreneurial intent and the models that have been used to identify the main factors involved, followed by the explanation of the methodology used for the collection and analysis of data. Then the results are presented, showing the factors and clusters that are certain to characterize the entrepreneurial intent of university students. Finally, there is a section of discussion and conclusions with the main findings.

The following describes the main theories and models used to explain entrepreneurial intent. The factors identified in the different studies and the results associated with intention in university students are highlighted.

\section{CONCEPTUAL FRAMEWORK}

\subsection{Analysis of entrepreneurial intent}

The analysis of entrepreneurial intent is the key to explain the process of creation of companies (Devonish et al. 2010; Liñán y Fayolle 2015) this is why various studies have sought to identify the key factors affecting individuals regarding the decision to start up a Company (Liñan et al. 2005; Obschonka and Rodermund 2010; Valencia, Montoya and Montoya, 2016). These studies have been focused on aspects ranging from the determination of behavioral theories that leads a person to make decisions (Boissin et al. 2011; Ferreira et al. 2012) to the formulation of models describing the relationships and associations between factors affecting the entrepreneurial intent of individuals (Lanero et al. 2014; Hui-Chen et al.2014). 
Some of the theoretical models worth highlighting, among those that have been formulated in relation to the intent people have to create a company, are the Entrepreneurial Event Model (EEM) by Shapero and Sokol (1982) and the Theory of Planned Behavior (TPB) by Ajzen (1991). The first one states that the intention of starting a company depends on three sets of elements: individual choice for starting a new company, the perception of viability, and the propensity to act in the face of new business opportunities (Krueger et al. 2000). The Theory of Planned Behavior states that, when behavior is rational, the best predictor of action is intention, and three variables preceding the formation of that intention are paramount: attitude, subjective norms, and perceived control on such behavior (Kautonen et al. 2013). This theory has become, in recent years, the most commonly used to explain entrepreneurial intent (Valencia et al. 2015a; Lortie and Castogiovanni 2015).

Subsequently, Krueger and Brazeal (1994) proposed the Entrepreneurial Potential Model (EPM), which is based on the models of Shapero and Sokol (1982) and Ajzen (1991), integrating the concepts of perception, desirability, and feasibility. The model is based on the idea that the individual's propensity to act along with their credibility determines their entrepreneurial potential; it also explains that, although the individual perceives creating a new company as viable and desirable, this is not reason enough for that actually taking place (Guerrero et al. 2008). To this end, it is proposed that there should be a "trigger event" that makes the potential entrepreneur become a real intention. Elfvinget al (2009) interpret this event as something that can change the entrepreneurial goals of people at any point in life by a specific situation that made them see reality differently. In this sense, we propose the following elements of entrepreneurial intent in university students below.

\subsection{Entrepreneurial intent among university students}

A group that raises particular interest among the population groups in the research regarding entrepreneurial intent comprises university students (Montoya et al. 2016), as they have high chances of becoming potential entrepreneurs (Olsen 2013). This is because it is in college where people tend to define their life project, which varies according to their personal characteristics and their social context (Hong et al. 2012).

To teach entrepreneurship, it is necessary to have multisectoral commitment (Fayolle and Gailly 2015) with the participation of enterprises and industrial institutions, the financial sector, and national and regional economic development entities (Binks et al. 2006).

Despite all the joint effort of the actors, often times training in entrepreneurship by HEI is not carried out adequately (Shinnar et al. 2014; Moriano et al. (2006) explain that there are "unintentional" social barriers that are based on the lack of support to student entrepreneurs, i.e., in many occasions teachers educate and treat their students as future employees and not entrepreneurs.

The studies conducted on intentions to create a company among university students have been applied on samples of students of different academic programs (Hattab 2014), different levels of progress in their academic programs (Mohd et al. 2014), variable age ranges (Neneh 2014), and in general, different socio-economic contexts.

In Latin America, Espiritu (2011) managed to determine the degree of dependence of the variables of internal control of the person, the need for achievement and risk, with their entrepreneurial intent; Valencia et al. (2012) conclude that there is a significant asso- 
ciation between the convenience and the perceived feasibility of entrepreneurship. They also found a weak association between risk tolerance and other factors related to entrepreneurial intent. On the other hand, in Mora (2011), the risk factor is shown as an element that adversely affects the entrepreneurial intent of people, especially in aspects related to innovation (Maussa et al. 2016), motivation for achievement, and perceived control; which in turn, were identified as components with great explanatory power in entrepreneurial behavior. The study conducted by Soria (Soria et al. 2016b) is also worth mentioning. In it, the presence of the "risk aversion" variable becomes explicit as an element that binds the positive relationship between self-efficacy internal control and entrepreneurial intent among college students. Finally, the results of the studies conducted by Espíritu (2011); Paez and García (2011) and Mora (2011) are also worth highlighting, as they identified the factor of motivation for achievement as a common aspect, in addition to other factors, and which has a high explanatory power over a person's entrepreneurial intent (Mokhtar and Zainuddin 2011).

\section{METHODOLOGICAL DESIGN}

This research is based on a quantitative methodological design, which used a self-administered questionnaire applied to 1290 students in three HEI in Medellín (Colombia) as a tool for gathering primary information. The participating HEI were Corporación Universitaria Minuto de Dios, Instituto Tecnológico Metropolitano (ITM), and Universidad de Medellín, with students belonging to various programs and academic levels. Out of the 1290 surveys carried out, 879 were validated for the analysis of results. The main characteristics of the population include the following: $64.51 \%$ corresponds to students from the first 5 semesters (first to third year), and the remaining 35.51\% are between semesters 6 to 10 (third to fifth year). With regard to the majors they are pursuing, $44.14 \%$ and $26.39 \%$ belong to programs related to administration and socio-humanistic programs, respectively, and $29.49 \%$ belong to other programs. The average age of students is 23 , with a standard deviation of 5.3 years.

The questionnaire was divided into two parts: the first one had six qualitative questions related to general comments and views on the topic of entrepreneurship, as well as information about the academic program and future perspective (these questions are coded as $\mathrm{E}_{1}, \mathrm{E}_{2}, \mathrm{E}_{3}, \mathrm{E}_{4}, \mathrm{E}_{5}$, and $\mathrm{E}_{6}$ ); and the second part, which was made up of 17 questions based on factors related to the Model of Entrepreneurial Intent (MEI), includes aspects related to the perceived convenience and feasibility, motivation for achievement, and risk tolerance (Segal et al. 2005) (coded as $\mathrm{I}_{1}, \mathrm{I}_{2}, \mathrm{I}_{3}, \ldots, \mathrm{I}_{17}$ ). These questions are made in a Likert scale with the following response options: Strongly agree, agree, neither agree nor disagree, disagree, and strongly disagree.

The collection of information from students was conducted during the first half of 2015, through non-probabilistic sampling by criterion. After the data were captured, the instrument was validated by Cronbach Alpha statistics to discuss the reliability of scales in the questions of the survey. This yielded a result of 0.884 , demonstrating high reliability in the data obtained (George and Mallery 2003). 
The type of research conducted is multivariate descriptive, with the use of the statistical technique of Principal Components Analysis (PCA), making it possible through multiple associations to summarize the set of variables in factors or components determining the greatest weight of explanation in data variance (Peña 2002). For this analysis, the 17 variables named $I_{i}$ were used; and subsequently, a cluster analysis was conducted on them in order to identify and differentiate groups of students with similarity or dissimilarity related to their entrepreneurial intent. In this part, we also used the $\mathrm{E}_{\mathrm{i}}$ qualitative variables as illustrative variables to complement the identification of patterns of behavior and improve the characterization of clusters, but these gave no contribution or weight for their creation. This is based on the theory that cluster analysis seeks to organize units of study (in this case the students) into groups, so that the degree of natural association is high among the members of the same group and low among members of different groups (Esofier and Pages 1992).

\section{RESULTS}

The following are the results obtained from the analysis of the data performed. Generally speaking, $52.1 \%$ of students believe that their level of training in creation of companies is average $\left(\mathrm{E}_{2}\right)$, and more than $90 \%$ are interested in receiving training in issues associated with entrepreneurship $\left(\mathrm{E}_{3}\right)$. Additionally, $80.2 \%$ of the population has been through some event that motivates them to create their own company $\left(\mathrm{E}_{5}\right)$, understanding that only $22.4 \%$ has done so $\left(\mathrm{E}_{6}\right)$.

Then, the factors that determine the entrepreneurial profile of students are referenced, and subsequently the characterization of entrepreneurial intent is established based on the clusters found.

\subsection{Factors that determine the entrepreneurial profile}

Table 1 shows the total variance explained and eigenvalues. To explore the factors that explain the entrepreneurial intent among students, we identified that the first three explained $55 \%$ of the total variation, and starting from the fourth, there is no significant change showing other important relationships or contributing to total data variability. Besides, based on this factor, eigenvalues are lower than one. In this regard, Peña (2002) noted as a rule to select only the components or factors associated with eigenvalues greater than one.

Table 1

Total variance explained and eigen values with risk factor

Total variance explained

Extraction sum of square loads Rotation sum of square loads

\begin{tabular}{cccccc}
\hline \multirow{2}{*}{ Component } & $\begin{array}{l}\text { Initial } \\
\text { eigen- } \\
\text { values } \\
\text { (total) }\end{array}$ & $\begin{array}{c}\text { Percentage of } \\
\text { variance }\end{array}$ & $\begin{array}{l}\text { Cumulative } \\
\text { percentage }\end{array}$ & $\begin{array}{c}\text { Percentage of va- } \\
\text { riance }\end{array}$ & $\begin{array}{c}\text { Cumulative } \\
\text { percentage }\end{array}$ \\
\hline
\end{tabular}


J. A. Torres Velásquez / A. Valencia Arias / J. Bermúdez Hernández / L. F. Díez-Echavarría / M. L. Urrego Marín / F. O. Maussa Pérez.

\begin{tabular}{cccccc}
\hline 1 & 6,657 & 41,609 & 41,609 & 26,835 & 26,835 \\
\hline 2 & 1,115 & 6,969 & 48,578 & 21,408 & 48,242 \\
\hline 3 & 1,027 & 6,422 & 55,000 & 6,758 & 55,000 \\
\hline 4 & 0,957 & & & \\
\hline
\end{tabular}

Source: Own elaboration.

To demonstrate the validity of the weights of the components evidenced in Table 1, we conducted Barlet's sphericity test (Table 2), which evaluates the applicability of factorial analysis on the variables studied. It is worth clarifying that each of the components shows the existence of factors that have an important input in the analysis. The test showed that the model is significant by rejecting the assumption of sphericity of the sample data, i.e., the idea that there is no correlation between the variables was rejected. Another test that was conducted was the Kaiser-Meyer-Olkin test (KMO), with a result of 0.938 (Table 2), meaning that the partial correlation between the factors is high, i.e., there is a good alignment of data to a factor analysis model. It should be recalled that for values higher than 0.8 the test results are highly relevant (Frohlich y Westbrook 2001).

Table 2

\section{KMO and Bartlett's test}

\begin{tabular}{lll}
\hline Kaiser-Meyer-Olkin test & & 0,938 \\
\hline \multirow{3}{*}{ Barlet's sphericity test } & Chi square & 5682,603 \\
\cline { 2 - 3 } & df & 120 \\
\cline { 2 - 3 } & Next. & 0,000 \\
\hline
\end{tabular}

Source: Own elaboration.

In order to identify the factors that explain most of the variability of the data, we conducted orthogonal rotation through the maximum variance method, which minimizes the number of variables with high saturations in each factor and simplifies the interpretation of the variables analyzed, optimizing the solution by column (Kaiser 1958). As a result, the rotated components showed three factors (Table 3), which comprise the variables with the greatest weight, as follows: the first component represents the factor comprising the variables $\mathrm{I}_{1}, \mathrm{I}_{2}, \mathrm{I}_{3}, \mathrm{I}_{6}$, and $\mathrm{I}_{15}$; the second is represented by variables $\mathrm{I}_{10}, \mathrm{I}_{14}$, and $\mathrm{I}_{16}$, and the third component only has variable $\mathrm{I}_{8}$, as it had no significant relation with any other.

Table 3

\begin{tabular}{lccc}
\multicolumn{3}{c}{ Components matrix } \\
\hline & \multicolumn{3}{c}{ Factor } \\
\cline { 2 - 4 } & 1 & 2 & 3 \\
\hline I1 & 0,645 & --- & --- \\
\hline I2 & 0,673 & --- & --- \\
\hline I3 & 0,758 & --- & --- \\
\hline
\end{tabular}




\begin{tabular}{lccc}
\hline I6 & 0,645 & --- & --- \\
\hline I8 & --- & --- & 0,884 \\
\hline I10 & --- & 0,760 & --- \\
\hline I14 & --- & 0,705 & --- \\
\hline I15 & 0,647 & --- & --- \\
\hline I16 & --- & 0,717 & --- \\
\hline
\end{tabular}

Source: Own elaboration

Table 4 shows the representation of each factor regarding the variables that comprise it. The first factor can be defined as aspects that have to do with the behavior, attitude, and intention regarding the entrepreneurship of students and perceived viability; the second is related to motivational aspects with regard to improving their lifestyle or perceived convenience by virtue of being an entrepreneur (Segal et al. 2005). Finally, the third factor appears with only one viable with significant weight, $\mathrm{I}_{8}$, which is described as the attitude regarding the risk of creating a company. It is noteworthy that factors 1 and 2 managed to explain $48.24 \%$ of variance and factor 3 , risk aversion, explains only $6.7 \%$ of variance; therefore, in this study, variable $\mathrm{I}_{8}$ was removed in order to increase the explanation of variability and focus it on factors 1 and 2 .

Table 4

Main components, variance and variables that comprise it

\begin{tabular}{|c|c|c|c|c|c|}
\hline Component & $\begin{array}{l}\% \text { Variance } \\
\text { with risk } \\
\text { factor }\end{array}$ & $\begin{array}{c}\% \text { Variance } \\
\text { without risk factor }\end{array}$ & $\begin{array}{l}\text { Component } \\
\text { description }\end{array}$ & Variable & $\begin{array}{l}\text { Variable description } \\
\text { or question }\end{array}$ \\
\hline \multirow{5}{*}{ Factor 1} & \multirow{5}{*}{26,83} & \multirow{5}{*}{32,59} & \multirow{5}{*}{$\begin{array}{l}\text { Behavior, } \\
\text { attitude and } \\
\text { perceived } \\
\text { viability }\end{array}$} & I1 & $\begin{array}{l}\text { I can develop and } \\
\text { maintain favorable } \\
\text { relationships with } \\
\text { potential investors }\end{array}$ \\
\hline & & & & $\mathrm{I} 2$ & $\begin{array}{l}\text { It is attractive for my } \\
\text { and convenient for an } \\
\text { entrepreneur }\end{array}$ \\
\hline & & & & I3 & $\begin{array}{l}\text { I am able to generate } \\
\text { strategies to look for } \\
\text { market opportunities } \\
\text { in the environment. }\end{array}$ \\
\hline & & & & I6 & $\begin{array}{l}\text { I see the option of } \\
\text { starting a business as } \\
\text { a potential opportu- } \\
\text { nity that I could fight } \\
\text { for. }\end{array}$ \\
\hline & & & & I15 & $\begin{array}{l}\text { My professional } \\
\text { objective is to be an } \\
\text { entrepreneur }\end{array}$ \\
\hline
\end{tabular}




\begin{tabular}{|c|c|c|c|c|c|}
\hline \multirow{3}{*}{ Factor 2} & \multirow{3}{*}{21,40} & \multirow{3}{*}{27,17} & \multirow{3}{*}{$\begin{array}{l}\text { Perceived } \\
\text { convenience }\end{array}$} & I10 & $\begin{array}{l}\text { Creating a business } \\
\text { can improve work-life } \\
\text { balance. }\end{array}$ \\
\hline & & & & I14 & $\begin{array}{l}\text { As an entrepreneur } \\
\text { you have a better } \\
\text { lifestyle. }\end{array}$ \\
\hline & & & & I16 & $\begin{array}{l}\text { Being an entrepreneur } \\
\text { implies more advan- } \\
\text { tages than disadvanta- } \\
\text { ges for me. }\end{array}$ \\
\hline Factor 3 & 6,75 & --- & $\begin{array}{l}\text { Risk tole- } \\
\text { rance }\end{array}$ & I8 & $\begin{array}{l}\text { Creating a company is } \\
\text { very risky. }\end{array}$ \\
\hline
\end{tabular}

Source: Own elaboration.

After eliminating factor 3 (risk aversion), which contributed to total variance in a negligible way, the main components were calculated again. It is then noted in Table 5 that now the first two factors explain $59.77 \%$ of the total variation; there is also evidence that starting from the third component, the eigenvalue is 0.752 , less than 1 (Peña 2002); therefore, the first two factors are the most relevant to explain variability.

Table 5

Total variance explained and eigenvalues without risk factor

\begin{tabular}{cccccc}
\hline \multicolumn{5}{c}{ Total variance explained } \\
\hline Component & $\begin{array}{c}\text { Extraction sum of square } \\
\text { loads }\end{array}$ & \multicolumn{2}{c}{ Rotation sum of square loads } \\
\hline 1 & 3,720 & 46,497 & 46,497 & 32,599 & 32,599 \\
\hline 2 & 1,062 & 13,279 & 59,776 & 27,177 & 59,776 \\
\hline 3 & 0,752 & 9,395 & & & \\
\hline
\end{tabular}

Source: Own elaboration.

With regard to the new contribution matrix of the factors, it can be seen in Table 6 that with the removal of variable $\mathrm{I}_{8}$ (risk aversion) there are only two factors left with the same variables as in Table 3, but with greater weighting for each of them. The first factor is formed by variables $I_{1}, I_{2}, I_{3}, I_{6}$, and $I_{15}$, related to the perceived feasibility of entrepreneurship and the second by $\mathrm{I}_{10}, \mathrm{I}_{14}$, and $\mathrm{I}_{16}$ with perceived convenience. Similarly, Table 4 shows the behavior of variability with and without the risk factor, comparatively, and it becomes clear that the first two factors initially provided $48.24 \%$, and excluding the risk factor, this reached almost $60 \%$. 
Table 6

\section{Components matrix (without risk factor)}

\begin{tabular}{ccc}
\hline & \multicolumn{2}{c}{ Factor } \\
\cline { 2 - 3 } & 1 & 2 \\
\hline I1 & 0,705 & --- \\
\hline I2 & 0,713 & --- \\
\hline I3 & 0,788 & --- \\
\hline I6 & 0,649 & --- \\
\hline I10 & --- & 0,773 \\
\hline I14 & --- & 0,758 \\
\hline I15 & 0,658 & --- \\
\hline I16 & --- & 0,741 \\
\hline
\end{tabular}

Source: Own elaboration

\subsection{Entrepreneurial characterization of students}

Once the factors affecting the appearance of differences and similarities in the students' entrepreneurial profile have been identified, regarding entrepreneurial attitude and motivation, characterization is presented using a cluster, which makes it possible to group students into categories according to their similarity in their patterns of behavior regarding entrepreneurial intent. First, each cluster is formed by their similarity in the average rating and standard deviation obtained as a result of variable metric. The identification of the prevailing or important variables in forming the group is based on the distance of their average rating (given within the group) with regard to their global average rating. The groups with highly differentiated behaviors are identified because the averages of their variables are dissimilar to the rating of global averages, whether positively or negatively. The intermediate or transition (neutral) group or groups have a high degree of influence of mid-range response mode (or with indecisive response), and are characterized by having their average data close to the average global variables (in absolute value).

Another element to take into account is related to the internal and external variation of each cluster, i.e., the distance between them. For purposes of this study, this was based on nearly $60 \%$ of the total variance explained by the first two factors. It is also clear that the creation of said cluster had as criteria, in addition to the factors mentioned above, the average rating obtained in each variable and its standard deviation. The last is expected to be low or relatively low within the cluster for it to have significant explanatory power.

In this sense, it is clear that, in the first group, called "entrepreneurs," data variation is relatively small (Table 7), i.e., good homogeneity is evident; whereas, in the third group, "non-entrepreneurs," the opposite happens. This means that it is a group that is internally less homogeneous in its entrepreneurial thinking; that is, despite having unfavorable responses toward entrepreneurship, it is a little more dissimilar than the other two groups, internally speaking. 
The structure of the cluster is based on the variables classified as $I_{i}$ that have the objective of measuring the entrepreneurial intent of students, and additionally, $\mathrm{E}_{\mathrm{i}}$ variables were taken as illustrative variables. These enable conducting a characterization with more information on the patterns of behavior of the cluster, but they are not key nor have the weight to obtain the characterized clusters. Some variables did not have enough weight for the creation of the cluster, which is the case of $\mathrm{I}_{1}$ and $\mathrm{I}_{10}$, which did not contribute to the construction of the "entrepreneurs" cluster but did to that of the "non-entrepreneurs" one (see table 7). The same is true for some illustrative variables named $\mathrm{E}_{\mathrm{i}}$, which despite the fact that they make it possible to characterize qualitative aspects to understand the cluster's behavior in a more global way, they do not impact their formation (Table 8).

\subsection{Establishment of entrepreneurial intent clusters}

As mentioned before, the first three factors explain a significant weight of the total variation; the plane formed by factors 1 and 2, which explains $59.77 \%$ of it, determines three clusters that are similar in their types of responses in the entrepreneurial variables. Table 7 shows the first group comprising $36.18 \%$ of the students (group of entrepreneurs), which is characterized by a high positive impact from the aspects of entrepreneurial intent, i.e., they agree or strongly agree that it is attractive to them to become entrepreneurs and see the option of establishing a company as an opportunity worth fighting for. Furthermore, they consider that as entrepreneurs they would have a better lifestyle and that there would be more advantages than disadvantages to being so; therefore, in general, their professional goal is to become entrepreneurs $\left(\mathrm{I}_{2}, \mathrm{I}_{6}, \mathrm{I}_{14}, \mathrm{I}_{15}, \mathrm{I}_{16}\right)$. It can also be observed that in this group about $89.31 \%$ have undergone a situation that has led them to become motivated about creating their own company $\left(\mathrm{E}_{5}\right), 96.54 \%$ finds it interesting to get information about the topic $\left(\mathrm{E}_{3}\right)$, and $29.87 \%$ has created and/or run their own business at some point $\left(\mathrm{E}_{6}\right)$ (Table 8$)$.

Table 7

Variable about cluster or groups

\begin{tabular}{cccc}
\hline "Entrepreneurs" & "Neutral" & "Not-Entrepre- & General statistics, \\
$(36.18 \%)$ & $(44.71 \%)$ & neurs" $(19.11 \%)$ & (sample)
\end{tabular}

\begin{tabular}{ccccccccc}
\hline $\begin{array}{c}\text { Varia- } \\
\text { ble }\end{array}$ & Mean & $\begin{array}{c}\text { Standard } \\
\text { deviation }\end{array}$ & Mean & $\begin{array}{c}\text { Standard } \\
\text { deviation }\end{array}$ & Mean & $\begin{array}{c}\text { Standard } \\
\text { deviation }\end{array}$ & Mean & $\begin{array}{c}\text { Standard } \\
\text { deviation }\end{array}$ \\
\hline I1 & --- & --- & --- & --- & 3.36 & 0.89 & 4.01 & 0.80 \\
\hline I2 & 4.92 & 0.29 & --- & --- & 3.31 & 1.01 & 4.39 & 0.83 \\
\hline I3 & 4.54 & 0.57 & --- & --- & 3.14 & 0.88 & 4.02 & 0.84 \\
\hline I6 & 4.83 & 0.43 & --- & --- & 3.16 & 0.94 & 4.20 & 0.88 \\
\hline I10 & --- & --- & 3.75 & 0.88 & 3.21 & 0.92 & 3.93 & 0.97 \\
\hline I14 & 4.68 & 0.55 & 3.74 & 0.75 & 3.12 & 0.91 & 3.96 & 0.93 \\
\hline I15 & 4.70 & 0.57 & 3.84 & 0.73 & 2.74 & 0.87 & 3.94 & 1.00 \\
\hline I16 & 4.60 & 0.61 & 3.66 & 0.73 & 2.98 & 0.82 & 3.87 & 0.93 \\
\hline
\end{tabular}

Blanck spaces indicate that the variable does not have significant weight for the formation of the cluster. Source: Own elaboration. 
Another group that is completely opposite to the previous one in its entrepreneurial intent is group 3, "non-entrepreneurs" (Table 7), which comprises $19.11 \%$ of students, and has a negative or mid-range perception in almost all the same aspects as the "entrepreneurs" group. In this group, there is low or medium interest in having the goal of becoming an entrepreneur, there is the idea that entrepreneurs do not necessarily have a better lifestyle, and that becoming one does not necessarily entail more advantages than disadvantages $\left(\mathrm{I}_{14}, \mathrm{I}_{15}, \mathrm{I}_{16}\right)$. On average, they do not agree nor disagree that starting up a new business is attractive to them $\left(\mathrm{I}_{2}\right), 69.05 \%$ are interested in receiving training on the topic $\left(\mathrm{E}_{3}\right)$, and additionally, $33.93 \%$ and $60.12 \%$ have a level of training in entrepreneurship that is medium or low, respectively $\left(\mathrm{E}_{2}\right)$; (Table 8).

Table 8

\section{Illustrative characteristics of the cluster}

\begin{tabular}{ccccccc}
\hline Variable & \multicolumn{2}{c}{ "Entrepreneurs" $(36.18 \%)$} & \multicolumn{2}{c}{$\begin{array}{c}\text { "Neutral” } \\
(44.71 \%)\end{array}$} & "Not-Entrepreneurs" (19.11\%) \\
\hline \multirow{2}{*}{ E2 } & High & 13.52 & High & 6.11 & High & --- \\
\cline { 2 - 7 } & Medium & --- & Medium & 57.76 & Medium & 33.93 \\
\cline { 2 - 7 } & Low & 31.76 & Low & --- & Low & 60.12 \\
\hline \multirow{2}{*}{ E3 } & Yes & 96.54 & Yes & 96.95 & Yes & 69.05 \\
\cline { 2 - 8 } & No & 3.96 & No & 3.05 & No & 30.95 \\
\hline \multirow{2}{*}{ E5 } & Yes & 89.31 & Yes & --- & Yes & 58.93 \\
\cline { 2 - 7 } & No & 10.69 & No & --- & No & 41.07 \\
\hline \multirow{2}{*}{ E6 } & Yes & 29.87 & Yes & --- & Yes & --- \\
\cline { 2 - 7 } & No & 70.13 & No & --- & No & --- \\
\cline { 2 - 7 }
\end{tabular}

Source: Own elaboration.

Group 2 appears as the "neutral" group in the last place, and it comprises $44.71 \%$ of the students (Table 7). This group shares characteristics with the "entrepreneurs" and "non-entrepreneurs," as it is statistically located between the two. This turns out to be an average group in their way of thinking in regard to starting up a company (Table 7). Their responses revolve around their mildly agreeing with the questions about attitude and capability to start up a business; i.e., they are not clear on their goal being that of becoming an entrepreneur, on the fact that entrepreneurs have a better lifestyle, and on the fact that entrepreneurs have more advantages than disadvantages. This group is also characterized by the fact that $96.95 \%$ of its members find it interesting to be trained in business creation. Also, $57.76 \%$ of its members have a mid-range training level (Table 8 ). It is necessary to take into account that the average values of this group are slightly smaller than the general average, which imples a closer resemblance to the group of "non-entrepreneurs" than to that of "entrepreneurs."

Another element identified in the analyzed population is related to students who have created and/or run their own company $\left(E_{6}\right)$. Among these, $26.67 \%$ of those who have 
experienced a situation that has motivated them to create their own business have really done so, while out of those who haven't have experienced this situation, only $5.17 \%$ have materialized it. Krueger and Brazeal (1994) called this a "trigger event", which was mentioned above.

\section{DISCUSSION}

Regarding the identification of the factors that explain a relatively high percentage of variance in the information obtained from the university students, a first factor is observed, characterized by aspects related with convenience, the need for achievement, and viability regarding entrepreneurship. This is consistent with Mohd et al. (2014) findings, as they propose that descriptive and inferential statistical analyses revealed a significant relation between entrepreneurial intent, the need for achievement, and self-efficacy. In addition, this first factor shows the student as a being that wishes, finds it viable, and has as a primary goal to create their own company, and also as a reasonable being that considers that doing so requires strategies and skills in an environment of opportunities. In this regard, Pihie and Akmaliah (2009) propose that universities and government organizations are responsible for the creation of businesses and competitive skills among students in order to guide them toward the creation of enterprises with high added value, from the establishment of policies to encourage the creation of companies. Furthermore, the creation of companies that emerge from research processes in university contexts must be encouraged, as these have greater added value and promote interaction between academia and industry (Díez, Valencia and Villa, 2015).

A second factor shows the student as a being with needs who acknowledges the fact that being an entrepreneur will give them more advantages than disadvantages, a better lifestyle, and good work-life balance. On the other hand, and as a last factor, there is the risk of creating a company, which appears to have little correlation with the rest of the variables and in which students are somewhat averse. In the study conducted by Valencia et al. (2015b), this factor showed a weak association regarding the other factors of entrepreneurial intent.

In accordance with this, it is proposed that the independence generated by becoming an entrepreneur and the perception of creating a company as a factor that will improve quality of life makes it less attractive for students to become employees (Cassar 2007). However, it has been found that these factors are not homogeneous and they depend on the type of company that one desires to create and the foresight one has regarding one's future as entrepreneurs. For example, Manolova et al. (2012) found that while men with entrepreneurial intent are seeking financial success, women are more inclined towards personal satisfaction, among other differences.

One additional element is the characterization of the students according to their entrepreneurial behavior through the attainment of three clusters: the "entrepreneurs," the "non-entrepreneurs," and the "neutral" group, with percentages of 36.18\%, 19.11\%, and $44.71 \%$, respectively. The group of "entrepreneurs" can be seen as the group that has a great power of conviction toward entrepreneurship as a good alternative. It is also worth highlighting that in this group, $89.31 \%$ of people have undergone a situation that has mo- 
tivated them to create their own business at some point $\left(\mathrm{E}_{5}\right)$, which is contrary to the situation of "non-entrepreneurs," in which $58.93 \%$ of people have been affected by this situation or event motivating them to start up a company. Krueger and Brazeal (1994) interpret this as a "trigger event," by considering that it is not enough for the individual to perceive creating a company as feasible and desirable, but also that it is necessary that such event occurs at some point in their life.

On the other hand, while there is a positive attitude and capability regarding the action of starting up a business among the "entrepreneurs" group, there is no evident significant weight in having a high level of training in business creation (only $13.52 \%$ has it), even though $96.54 \%$ is interested in receiving this kind of training $\left(\mathrm{E}_{3}\right)$. In higher education institutions, it is common to find that there is no training in entrepreneurship, mainly due to the perception that students are future employees and not future entrepreneurs (Kouriloff 2000). Some authors, such as Moriano et al. (2006), consider this situation as unintentional social barriers that prevent entrepreneurship among students.

Therefore, in order to achieve an effective increase in entrepreneurial intent, it is recommended that there is guidance into strategies that are more focused on the change of personal attitudes rather than on theoretical knowledge taught, since the effects are more significant when these programs are emphasized in overcoming perceived barriers in order to foster entrepreneurial initiative (Raposo and Do Paço 2011). This situation in particular is presented by Soriaet al (2016a), who showed in their study related to education and entrepreneurial intent among university students that after taking a training course on entrepreneurship, entrepreneurial intent decreased in relation to the level noted by students at the beginning of the course.

Regarding the "neutral" group, despite the fact that it presents an "indecisive" response regarding attitude and aptitude toward their intention of starting up a business, it has been noted that $96.26 \%$ are interested in receiving training on the subject $\left(\mathrm{E}_{3}\right)$. This is a value that is very close to that in the "entrepreneurs" group, and much lower in comparison to the "non-entrepreneurs" group (69.05\%). This indicates that despite showing an "indifferent" perception toward entrepreneurship as a good option, both the "neutral" and the "non-entrepreneurs" groups may also conceive it as a good alternative for their future, which might be achieved as long as policies of support and awareness-raising are put in place by the government, universities, and other actors, as training in entrepreneurship requres multisectoral participation and commitment (Binks et al. 2006; Valencia and Benjumea, 2013).

This is why it is necessary to focus efforts through policy that encourages entrepreneurship among college students, especially in this target audience that has an "indecisive" attitude toward the creation of companies, leveraging this propensity to receive training in the subject. This, taking into account that by making it possible for this target audience to have high levels of knowledge in the subject, it is possible to generate better personal attitudes toward business creation (Tshikovhi and Shambare 2015). In addition, it is believed that personal attitudes are the variable of mediation between preparation to create a company and the intention to create it, suggesting that the educational environment in which students find themselves plays a leading role in the strengthening of positive personal attitudes towards entrepreneurship (Zeng et al. 2011). 


\section{CONCLUSIONS}

With this study, it was found that entrepreneurial behavior and intent among university students can be explained by factors that relate aspects of behavior, attitude, and viability regarding entrepreneurship as a first factor, motivational aspects regarding the improvement of their lifestyle or perceived convenience as second factor, and attitude regarding risk as a third factor (Segal et al., 2005).

The risk factor is critical in light of the analysis of entrepreneurial intent, as it showed a low level of association with other factors, and therefore, it appears as a factor built on a single variable. The results obtained showed that the students demonstrated a high risk aversion, which requires a more comprehensive analysis. By having this a variable as a single factor, it may be necessary to establish other variables of the same type in order to make it more representative in the analysis and enable more conclusive evidence.

There is evidence of a latent interest in receiving training in the topic of entrepreneurship by students. This situation must be seen by higher education institutions as an opportunity to improve their training processes and include this aspect in their programs, and also to involve actors in these processes, so that synergies are established in in pursuit of common objectives.

Another aspect is related to the fact that, if the students are unaware of the support programs universities and institutions have in place, which guide the creation of companies, it can lead to a lack of interest in creating companies. This is evidence of the lack of effectiveness of the HEI in informing and educating its students about the support they have from programs, not only regarding economic support, but also related to management.

It is important to highlight that the analysis presented in this article corresponds to results from university students in higher education institutions in Colombia, which is viewed as an emerging economy, and therefore, the factors identified that explain entrepreneurial intent are undoubtedly permeated by the social, cultural, and economic characteristics that are typical of countries like this, as opposed to the economies of developed countries that could vary significantly. In this sense, for future research, the possibility of designing and validating models in other scenarios in Latin America is proposed, as this may explain the factors associated to entrepreneurial intent in such contexts.

\section{REFERENCES}

Ajzen, I., 1991. The theory of planned behavior. Organizational Behavior and Human Decisión Processes. 50, 179-211. Available at: doi:10.1016/0749-5978(91)90020-T.

Audet. J., 2001. A Longitudinal Study of the Entrepreneurial Intentions of University Students d Université Laval. Enterprise and Innovation Management Studies, Vol. 2, No. 2, 2001, 145-160. Available at: https://www.researchgate.net/publication/265485034

Binks, M., Starkey, K., and Mahon, C., 2006. Entrepreneurship Education and the Business School. Technology Analysis and Strategic Management (18), 1-18. Available at: http:// dx.doi.org/10.1080/09537320500520411.

Boissin, J. P., Branchet, B., Delanoë, S., and Velo, V., 2011. Gender's perspective of role model influence on entrepreneurial behavioral beliefs. International Journal of Busi- 
ness, 16(2), 182. Available at: https://www.questia.com/library/journal/1P3-2442199471/ gender-s-perspective-of-role-model-influence-on-entrepreneurial.

Cassar, G., 2007. Money, money, money? A longitudinal investigation of entrepreneur career reasons, growth preferences and achieved growth. Entrepreneurship and Regional Development, 19(1), 89-107. Available at: http://dx.doi. org/10.1080/08985620601002246.

Devonish,D.,Alleyne,P.,Charles-Soverall,W.,Marshall,A., and Pounder,P.,2010.Explaining enterpreneurial intentions in the caribean. International Journal of Enterpreneurial Behaviour and Research , 149-171. Available at: doi: 10.1108/13552551011027020.

Díez, L., Valencia, A., and Villa, E., 2015. Promoción de la cultura investigativa como motor de desarrollo económico y social: una visión sistémica. Revista Espacios, 36(1), 3.

Elfving, J., Brannback, M., and Carsrud, A., 2009. Toward a contextual model of entrepreneurial intentions. En Understanding the Entrepreneurial Mind (págs. 23-33). New York: Springer Science + Business Media, LLC. Available at: doi: 10.1007/978-14419-0443-0_2.

Esofier, B., and Pages, J., 1992. Análisis factoriales simples y múltiples. Bilbao: Servicio Editorial de la Universidad del País Vasco.

Espiritu, R., 2011. Análisis de la intención emprendedora en estudiantes universitarios a través de los rasgos de personalidad. Multiciencias, 11(1), 65-75. Available at: http:// www.redalyc.org/articulo.oa?id=90418851009.

Fayolle, A., and Gailly, B., 2015. The impact of entrepreneurship education on entrepreneurial attitudes and intention: Hysteresis and persistence. Journal of Small Business Management, 53(1), 75-93. Available at: doi:10.1111/jsbm.12065.

Ferreira, J. J.; Raposo, M. L.; Rodrigues, R. G.; Dinis, A.; Do Paço, A., (2012). A model of entrepreneurial intention: An application of the psychological and behavioral approaches, Journal of Small Business and Enterprise Development, 19(3), 424-440.

Frohlich, M., and Westbrook, R., 2001. Arcs of integration: an international study of supply chain strategies. Journal Of Operations Management, 185-200. Available at: http:// dx.doi.org/10.1016/S0272-6963(00)00055-3.

George, D., and Mallery, P., 2003. SPSS for Windows step By step: a simple guide and reference (4th ed). Boston: Allyn and Bacon.

Guerrero, M., Rialp, J., and Urbano, D., 2008. The impact of desirability and feasibility on entrepreneurial intentions: A structural equation model. International Entrepreneurship and Management Journal, 4(1), 35-50. Available at: doi 10.1007/s11365-006-0032-x.

Hattab, H. W., 2014. Impact of entrepreneurship education on entrepreneurial intentions of university students in Egypt. Journal of Entrepreneurship, 23(1), 1-18. Disponible en doi: $10.1177 / 0971355713513346$.

Hong, Z., Hong, T., Cui, Z., and Luzhuang, W., 2012. Entrepreneurship Quality of College Students Related to Entrepreneurial Education. Energy Procedia, 17, 1907-1913. Available at: http://doi.org/10.1016/j.egypro.2012.02.331.

Hui-Chen, C., Kuen-Hung, T., and Chen-Yi, P., 2014. The entrepreneurial process: an integrated model. International Entrepreneurship and Management Journal, 10(4), 727 745. Available at: doi: 10.1007/s11365-014-0305-8.

Kaiser, H., 1958. The Varimax criterion for analytic rotation in factor analysis. Psychometrika, 23(3) , 187-200. Available at: doi: 10.1007/BF02289233. 
J. A. Torres Velásquez / A. Valencia Arias / J. Bermúdez Hernández / L. F. Díez-Echavarría / M. L. Urrego Marín / F. O. Maussa Pérez

Kautonen, T., Van Gelderen, M., and Tornikoski, E. T., 2013. Predicting entrepreneurial behaviour: a test of the theory of planned behaviour. Applied Economics, 45(6), 697707. Available at: doi: 10.1080/00036846.2011.610750.

Kouriloff, M., 2000. Exploring perceptions of a priori barriers to entrepreneurship: A multidisciplinary approach. Entrepreneurship: Theory and practice, 25(2), 59-59. Available at: https://www.highbeam.com/doc/1G1-74524633.html.

Krueger, N., and Brazeal, D., 1994. Entrepreneurial potential and potencial entrepreneurs. Entrepreneurship Theory and Practice 18(1), 5-21. Available at: http://dx.doi. org/10.1016/S0883-9026(98)00033-0.

Krueger, N. F., Reilly, M. D., and Carsrud, A. L, 2000. Competing models of entrepreneurial intentions. Journal of business venturing, 15(5), 411-432.

Lanero, A., Vázquez, J. L., and Muñoz-Adánez, A., 2014. A social cognitive model of entrepreneurial intentions in university students. Anales de Psicología/Annals of Psychology, 31(1), 243-259. Available at: doi: 10.6018/analesps.31.1.161461.

Liñan, F., Rodriguez, J., and Rueda, J., 2005. Factors affecting entrepreneurial intention levels. 45th Congress of the European Regional Science Association, (págs. 23-27). Amsterdam. Available at: doi: 10.1007/s11365-010-0154-z.

Liñán, F., Rodríguez-Cohard, J. C., and Rueda-Cantuche, J. M., 2010. Factors affecting entrepreneurial intention levels: a role for education. International Entrepreneurship and Management Journal, 7(12): 195-218.

Liñán, F., and Fayolle, A., 2015. A systematic literature review on entrepreneurial intentions: citation, thematic analyses, and research agenda. International Entrepreneurship and Management Journal, 11(4), 907-933. Available at: doi: 10.1007/s11365-0150356-5.

Lortie, J., and Castogiovanni, G., 2015. The theory of planned behavior in entrepreneurship research: what we know and future directions. International Entrepreneurship and Management Journal, 11(4), 935-957. Available at: doi: 10.1007/s11365-0150358-3.

Manolova, T. S., Brush, C. G., Edelman, L. F., and Shaver, K. G., 2012. One size does not fit all: Entrepreneurial expectancies and growth intentions of US women and men nascent entrepreneurs. Entrepreneurship and Regional Development, 24(1-2), 7-27. Available at: doi: 10.1080/08985626.2012.637344.

Maussa, F., Diez, L., Urrego, M., Valencia, A., Torres, J. and Bermudez, J., 2016. Acercamiento a la aplicación de la teoría de juegos evolutiva en el área de emprendimiento. Revista Espacios, 37 (14), 27-38.

Mohd, N., Maat, S. M., and Mat, S. C., 2014. Factors influencing entrepreneurial intention among engineering technology students. InProceedings of the 8th International Conference on Ubiquitous Information Management and Communication (p. 82). ACM.

Mokhtar, R., and Zainuddin, Y., 2011. Entrepreneurial Intention of Accounting Students in Malaysian Polytechnics Institutions: A Theory of Planned Behavior Approached. Proceedings of Global Business and Social Science Research Conference .

Montoya, R.I., Valencia, A. A., and Montoya, A., 2016. Mapeo del campo de conocimiento en intenciones emprendedoras mediante el análisis de redes sociales de conocimiento. Ingeniare. Revista chilena de ingeniería, 24(2), 337-350. Available at: http://dx.doi. org/10.4067/S0718-33052016000200015. 
Mora, R., 2011. Estudio de actitudes emprendedoras con profesionales que crearon empresa. Revista Escuela de Administración de Negocios, 70-83. Available at: http://journal. ean.edu.co/index.php/Revista/article/view/552.

Moriano, J., Palací, F., and Morales, J., 2006. The psychosocial profile of the university entrepreneur. Revista de sicología del trabajo y de las organizaciones, 75-99.

Neneh, B. N., 2014. An assessment of entrepreneurial intention among university students in Cameroon. Mediterranean Journal of Social Sciences, 5(20), 542.

Obschonka, M. S., and Rodermund, E., 2010. Entrepreneurial Intention as developmental outcome. Journal of Vocational Behavior, 63-72. Available at: http://dx.doi. org/10.1016/j.jvb.2010.02.008.

Olsen, M. A. K., 2013. Exploring Faculty Members Perceptions of Undergraduate Entrepreneurship Education.

Paez, D., and García, J., 2011. Acercamiento a las características del universitario emprendedor en la Unidad de Emprendimiento de la Universidad Nacional de Colombia. Revista Escuela de Administración y Negocios, 52-69. Available at: http://journal.ean. edu.co/index.php/Revista/article/view/551.

Peña, D., 2002. Análisis de datos multivariantes. Componentes principales (págs. $137-$ 171). España: Mc Graw-Hill.

Pihie, Z. A. L., and Akmaliah, Z., 2009. Entrepreneurship as a career choice: An analysis of entrepreneurial self-efficacy and intention of university students. European journal of social sciences, $9(2), 338-349$.

Raposo, M., and Do Paço, A., 2011. Entrepreneurship education: Relationship between education and entrepreneurial activity. Psicothema, 23(3). Available at: http://www. redalyc.org/articulo.oa?id=72718925018.

Segal, G., Borgia, D., and Schoenfeld, J., 2005. The motivation to become an entrepreneur. International Journal of Entrepreneurial Behavior and Research, 11(1), 42-57. Available at: doi: 10.1108/13552550510580834.

Shapero, A., and Sokol, L., 1982. The social dimensión of entrepreneurship. En C. Kent. D.L. Sexton and K.H. Vesper.Eds). The Encyclopedia of entrepreneurship.: Prentice H. Pag.72-90. Englewood Cliffs. NJ.

Shinnar, R. S., Hsu, D. K., and Powell, B. C., 2014. Self-efficacy, entrepreneurial intentions, and gender: Assessing the impact of entrepreneurship education longitudinally. The International Journal of Management Education, 12(3), 561-570. Available at: http://dx.doi.org/10.1016/j.ijme.2014.09.005.

Soria-Barreto, K., Zuñiga-Jara, S., Ruiz-Campo, S., 2016a. Educación e intención emprendedora en estudiantes universitarios: Un caso de estudio. Form. Univ. 9, 25-34. doi:10.4067/S0718-50062016000100004.

Soria-Barreto, K., Zuñiga-Jara, S., Ruiz-Campo, S., 2016b. Determinantes de la intención emprendedora: nueva evidencia/Determinants of entrepreneurial intention: new evidence/. Interciencia.

Tshikovhi, N., and Shambare, R., 2015. Entrepreneurial knowledge, personal attitudes, and entrepreneurship intentions among South African Enactus students. Problems and Perspectives in Management, 13 (1), 152-158.

Valencia, A., and Benjumea, M., 2013. Una visión del emprendimiento desde arquetipos sistémicos. Sinapsis, 5(5), 105-113. 
Valencia, A., Cadavid, L., Rios, E., and Awad, G., 2012. Factorres que inciden en las intenciones emprendedoras de los estudiantes. Revisa Venezolana de Gerencia, 132-148. Available at: http://www.redalyc.org/articulo.oa?id=29021992008.

Valencia, A., Montoya, I., and Montoya, A., 2015a. Factores explicativos de las intenciones emprendedoras en estudiantes universitarios. Revista Espacios, 36(5), 7-15. Available at: http://www.revistaespacios.com/a15v36n05/15360507.html.

Valencia, A. Montoya I and Montoya, A., 2015b. Influence of perceived behavioral control in entrepreneurial intentions of engineering students. Turkish Online Journal of Educational Technology. 7 (1). 341-347.

Valencia, A., Montoya, I. and Montoya, A., 2016. Intención emprendedora en estudiantes universitarios: un estudio bibliométrico. Intangible Capital, 12(4), 881-922 http://dx. doi.org/10.3926/ic.730.

Zeng, F. Q., Bu, X. Z., and Su, L., 2011. Study on entrepreneurial process model for SIFE student team based on Timmons model. Journal of Chinese Entrepreneurship, 3(3), 204-214. 
